TP Periodica Polytechnica Civil Engineering

\author{
60(2), pp. 281 287 2016 \\ DOI: $10.3311 /$ PPci.7744 \\ Creative Commons Attribution (1) \\ RESEARCH ARTICLE
}

\section{Resin Composites with High Chemical Resistance for Application in Civil Engineering}

\author{
Bernardeta Dębska, Lech Lichołai
}

Received 06-10-2014, revised 05-03-2015, accepted 05-01-2016

\begin{abstract}
The durability of building materials may be defined as a set of predesigned characteristics which the material preserves during possibly the longest period of use. Presently this is one of the basic criteria which decide about the choice of the appropriate material for building constructions. Contact with corrosioninducing factors causes building materials to deteriorate and shortens their service life. The article presents initial results of research into epoxide mortars modified with glycolysates based on poly(ethylene terephthalate) waste. The possibility of the application of thus chemical resistance upgraded mortars was discussed. The weight changes of the mortar samples after their exposure to five chosen corrosion-inducing media were found. The results obtained were shown as trend functions illustrating the weight changes of each sample with respect to the time of their exposure to the particular aggressive solution.
\end{abstract}

\section{Keywords}

epoxy mortar $\cdot$ PET recycling $\cdot$ statistical analysis $\cdot$ mechanical properties $\cdot$ chemical resistance

\section{Bernardeta Dębska}

Rzeszow University of Technology, Faculty of Civil and Environmental Engineering and Architecture, Poznańska 2, 35-959 Rzeszów, Poland e-mail: bdebska@prz.edu.pl

\section{Lech Lichołai}

Rzeszow University of Technology, Faculty of Civil and Environmental Engineering and Architecture, Poznańska 2, 35-959 Rzeszów, Poland e-mail: Lech.Licholai@prz.edu.pl

\section{Introduction}

Concretes and mortars have always been regarded as the most essential and widespread construction materials. They are composites made up of cement, water and aggregate. Chemical admixtures and mineral additives are mainly used in order to change the properties of such materials. Cement composites feature numerous advantages including high compressive strength, high temperature and fire resistance, easy use and a relatively low cost. These days, however, excellent chemical resistance is more and more often expected from construction materials apart from good strength properties. This stems, among other things, from increasingly higher levels of environmental contamination and, following on from this, the necessity to defend and enhance the durability of building structures. It is the durability and resistance against corrosion of construction materials that are the characteristics considered in recent years as the chief aim of the research into the process of modifying the existing materials and/or producing new composites of improved properties. Numerous research institutions have been conducting long-term research into the fabrication of new polymer concretes that can be successfully used for protecting structures against the harmful influence of aggressive agents [1-20].

\section{Polymer-modified concretes and mortars}

The properties of materials can be improved by appropriately modifying the composition of raw materials. As regards the modification of cement composites, polymers are considered to play such a key role. The type and amount of the polymer added are the two parameters critical to such materials' properties [21].

Polymer-modified cement composites fall into the following groups [22]:

- Cement concretes and mortars containing polymer admixtures or additives referred to as polymer modified cement concretes and mortars (PCC - Polymer modified Cement Concrete or PMC - Polymer Modified Concrete).

It is assumed that it does not suffice to introduce a modifier into a concrete mix at an amount of less than $5 \%$ of the cement mass to create a separate continuous phase in the setting mix and it is a so-called admixture. However, even such a 
small content of polymer may influence the composite's properties. On the other hand, polymer additives present in the cement mass at over 5\% are capable of forming an additional, continuous spatial structure, constituting together with the cement hydration products two interpenetrating each other and co-acting matrices. Enhanced resistance to the activity of corrosive products in such composites arises mainly from the fact that, by using polymers, a lower cement-water ratio can be applied consequently reducing material porosity and increasing its seal-tightness [22, 23].

- Polymer impregnated concretes and mortars (PIC - Polymer Impregnated Concrete)

They are obtained through impregnating the set concrete (mortar) with a polymer that is next polymerised within the concrete. The processes taking place reduce, among other things, porosity, create a polymer co-matrix, increase matrix adhesion to the aggregate, and consequently improve a variety of properties, including chemical resistance.

- Polymer concretes and mortars where a cement binder was completely replaced with a synthetic binder (PC - Polymer Concrete)

Resin composite is an innovative, state-of-the-art material perfectly meeting all the stringent durability and chemical resistance requirements and also possessing high mechanical strength. Resin binding is fundamental for improving resistance, especially chemical resistance, as compared to conventional concrete, for it eliminates the weakest component of conventional concrete, i.e. hydraulic mineral binding. The positive effect of polymers on the properties of the abovementioned concrete-like composites is shown in Table 1

As the disadvantages of the polymer concretes, the following properties can be listed:

- limited thermal and fire resistance,

- high thermal expansion,

- relatively high setting shrinkage,

- special conditions of production,

- special requirements regarding to the safety and hygiene, considering harmful action of unhardened resins and hardening systems, including emission of the toxic vapours,

- high material cost [21].

\section{Potential applications of resin mortars of enhanced chemical resistance}

Resin concretes are used only in special cases due to polymers' high cost. However, they are becoming increasingly popular on the market owing to their unique properties. The selected uses of polymer mortars, for which chemical resistance is of particular importance, are presented in this chapter.

\subsection{Adhesive mortars}

Adhesive mortars of special properties have to be applied for laying ceramic tiles in premises exposed to strong chemical ag- gression. Two-component products not containing any cement can by classified as such. These mortars are usually based on epoxy resin, which gives them very good resistance to chemical substances and good mechanical load strength. Good adhesion to most surfaces makes the material nearly universal. The products are also characterized by shrinkage-free setting and absence of internal stresses during bonding. They can be used on moisture sensitive and unstable surfaces. This makes such adhesive mortar indispensable in the case of demanding time-table constructions. Some mortars combine two functions: that of a reactive resin-based glue and of a pointing mortar. That kind of mortar is especially recommendable for surfaces of high chemical and mechanical resistance requirements, in particular in the industrial construction sector (e.g. swimming pools, industrial kitchens, showers, balconies, sewage treatment plants, breweries, dairies, saunas, wine factories, beverage plants, bottling plants, laboratories, chemical industry premises). Cement-free adhesive mortars are a perfect choice where aggressive fluids, brine, sea or mineral waters occur.

\subsection{Industrial floors}

One of the important applications of polymer composites is industrial floors which, apart from their high abrasion and scratch resistance as well as mechanical and impact strength, should also be characterised by chemical resistance. The last parameter is especially important where floors are exposed to aggressive solutions - food industry premises, laboratories, cold stores, warehouses. Jointless epoxy, resin-base floors are made in industrial facilities where systems meeting chemical resistance requirements must be used.

\subsection{Prefabricates}

Polymer concretes, owing to their properties, are also applied currently for manufacturing prefabricated products:

- for bridge draining systems (bridge cornices, bridge curbs, bridge inlets, drains);

- for linear drainage systems (channels, linear draining ducts, linear drainage wells);

- for industrial tanks for non-ferrous metals electrolysis;

- for wells and lines for discharging aggressive industrial effluent, water meter wells, sewage pumping stations;

- for manufacturing storage tanks resistant to aggressive substances such as acids, bases, etc.

The specific properties of the materials allow manufacturing chemically resistant linings such as chemically resistant coatings made of laminates or resign composites.

\subsection{Repair mortars}

Resin concretes and mortars have been used as a repair material for years. Their unique properties make them extremely useful for repairing bridge structures. The use of bridges in the open 
Tab. 1. Comparison of the properties of polymer-cement concretes, polymer impregnated concretes, resin concretes and Portland cement concretes 24]

\begin{tabular}{|c|c|c|c|c|}
\hline Properties & Cement concrete & PCC & PIC & PC \\
\hline Density kg/m3 & $2200-2400$ & $1800-2200$ & $2300-2400$ & $1850-2400$ \\
\hline $\begin{array}{l}\text { Compressive strength, } \\
\mathrm{MPa}\end{array}$ & $15-60$ & $20-75$ & $100-200$ & $40-150$ \\
\hline Flexural strength, $\mathrm{MPa}$ & $1.1-7.2$ & $2.5-20$ & $7.5-35$ & $4-55$ \\
\hline Tensile strength, $\mathrm{MPa}$ & $0.6-3.0$ & $4-9$ & $4-17$ & $4-20$ \\
\hline $\begin{array}{l}\text { Abrasion on Boehme disc, } \\
\mathrm{cm}\end{array}$ & $2-8$ & - & - & $0.1-0.35$ \\
\hline $\begin{array}{c}\text { Maximum use temperature, } \\
{ }^{\circ} \mathrm{C}\end{array}$ & 250 & $50-80$ & $125-150$ & $60-150$ \\
\hline Water absorbability, \% & $4-10$ & $1-15$ & $0.25-1.1$ & $0.03-3.0$ \\
\hline Corrosion resistance & poor or average & poor, average or good & good or very good & $\begin{array}{c}\text { good, very good or } \\
\text { excellent }\end{array}$ \\
\hline $\begin{array}{l}\text { Polymer content, \% of } \\
\text { concrete mass }\end{array}$ & - & $<30$ & $3-8$ & $6-20$ \\
\hline
\end{tabular}

involves their exposure to changing weather conditions (temperature fluctuations, rain water, acid rains, salt, high insolation). Traffic (vehicles) also have their impact causing changing load and vibrations. All this contributes to the relatively rapid development of bridge corrosion. Resin concrete can be used for concrete repairs in all bridge structure components. They should be used, though, whenever the repair area is not larger than 1 square meter.

\section{Chemical resistance of waste poly(ethylene tereph- thalate) (PET) glycolysate - modified epoxy resin - case study}

The aim of the research work conducted by the authors was to determine some selected properties of epoxy mortars where the resin was partly substituted with glycolysate obtained based on di-ethylene glycol and PET wastes. A cheaper product is obtained as a consequence of such modification of the mortars discussed while waste materials that usually pose a major environmental issue can be used at the same time for mortar production.

\subsection{The plan of the experiment}

To reduce the number of necessary experiments a statistical algorithm was made use of which allowed for a considerable reduction in the number of mortar specimens to be examined. The STATISTICA packet was used to create the plan of the experiment which took the form of a table (Table 1).

Each of the ten lines in the table presents one point of the plan and gives the parameters of the experiment that was conducted. The plan of the experiment that was chosen assumed a repetition of the investigation in the central point and that is why points 5 and 6 of the plan do not differ in their composition. The precise criteria connected with the choice of the plan of the experiment and its analysis are described in articles [25,26].
Tab. 2. List of parameters describing the composition of mortar for each point of the experiment plan

\begin{tabular}{ccc}
\hline $\begin{array}{c}\text { No of the point } \\
\text { of the plan }\end{array}$ & $\begin{array}{c}\text { Content of PET } \\
\text { \% by weight }\end{array}$ & $\begin{array}{c}\text { Resin weights/aggregate } \\
\text { ratio R/A }\end{array}$ \\
\hline $\mathbf{1}$ & 7.03 & 0.36 \\
\hline $\mathbf{2}$ & 2.06 & 0.33 \\
\hline $\mathbf{3}$ & 0.00 & 0.25 \\
\hline $\mathbf{4}$ & 7.03 & 0.14 \\
\hline $\mathbf{5}$ & 7.03 & 0.25 \\
\hline $\mathbf{6}$ & 7.03 & 0.25 \\
\hline $\mathbf{7}$ & 12.00 & 0.18 \\
\hline $\mathbf{8}$ & 12.00 & 0.33 \\
\hline $\mathbf{9}$ & 14.06 & 0.25 \\
\hline $\mathbf{1 0}$ & 2.06 & 0.18 \\
\hline
\end{tabular}

\subsection{Preparation of the specimens}

Resin mortar was prepared using Epidian 5 epoxy resin, Z1 hardener (triethylenetetramine), standard sand of a $0-2 \mathrm{~mm}$ grain size and poly(ethylene terephthalate) based on diethylene glycol.

The process of obtaining the mortars was broken up into three stages:

Stage 1. Obtaining epoxy composites modified with PET glycolisate by mixing appropriate amounts of epoxy resin and modifier. Then the components were held at a temperature of $358 \mathrm{~K}$ for 60 minutes, which enabled a reaction between the functional groups of the two components.

Stage 2. Hardening epoxy components by mixing a previously prepared compound with an appropriate amount of z-1 hardener (10 parts by weight/ $100 \mathrm{~g}$ of resin).

\section{Stage 3. Making epoxy resins}

The previously prepared resin compounds were mixed with standard sand in a laboratory mixer maintaining the same mixing time and number of revolutions per minute. The mortar obtained was put in $60 \times 60 \times 5 \mathrm{~mm}$ steel moulds.

To start the hardening process, the samples were left under the conditions defined by the relevant standard specification for 
seven days.

\subsection{Research description}

A prospect to use an epoxy mortar for, among other things, repairs and production of floors and prefabricated units working in an environment with high chemical aggression has led to studies the purpose of which was to assess the change in the properties of the selected components subjected to the activity of harmful factors. Weight changes were determined for mortar samples after exposing them to some selected corrosive mediums such as: $10 \%$ sulphuric acid solution, $10 \%$ nitric acid solution, $10 \%$ sodium hydroxide solution and $10 \%$ sodium chloride solution and distilled water. 30 mortar samples dimensioned $60 \mathrm{~mm}$ x $60 \mathrm{~mm} \times 5 \mathrm{~mm}$ were tested for each type of aggressive product after a week of ripening. Chemical resistance tests were performed at a temperature of $23 \pm 2^{\circ} \mathrm{C}$. The weight of each sample was recorded at an accuracy of $1 \mathrm{mg}$ after drying them down to the constant weight at $50 \pm 2^{\circ} \mathrm{C}$. The samples were then placed in containers each with a different corrosive solution. The amount of the solution used for the tests was adjusted in such a way that it made up not less than $8 \mathrm{ml}$ per square centimeter of the total sample surface and that it completely covered the sample. After immersing them for the appropriate period of time in the aggressive substance ( daily up to 7 th day, 2 weeks, 4 weeks, 16 weeks, 6 months and 12 months, respectively), the individual samples were removed, dried with paper (the same kind of paper and the same sample drying method were used) and then weighed. After being marked at the prefixed moments during the monitoring the mortar samples were again placed in containers with a corrosive substance and kept there until the next weighing. Weight changes in percentage terms $(\Delta w)$ were calculated for each sample from the following equation:

$$
\Delta w=\left(\left(w_{2}-w_{1}\right) / w_{1}\right) \cdot 100 \%
$$

where:

$w_{1}$ - sample weight in milligrams $(\mathrm{mg})$ after initial drying before immersion,

$w_{2}$ - sample weight in milligrams $(\mathrm{mg})$ weighed after fixed immersion time.

Additionally, colour changes of the tested samples were assessed visually.

\subsection{Analysis of epoxy resins' chemical resistance results}

It was decided that the results obtained would be presented as the trend function. Applying a uniform scale on the $\mathrm{x}$ - axis to mark the exposure time in the corrosive medium caused a higher density of points at the beginning of the axis, whereas the points describing the average changes in weight after six months or after a year were much farther from the other points. In that case it seemed reasonable to introduce a logarithmic scale on the $\mathrm{x}$ - axis. Such an approach forced the selection of the trend function as the exponential function:

$$
z=b e^{a \cdot x}
$$

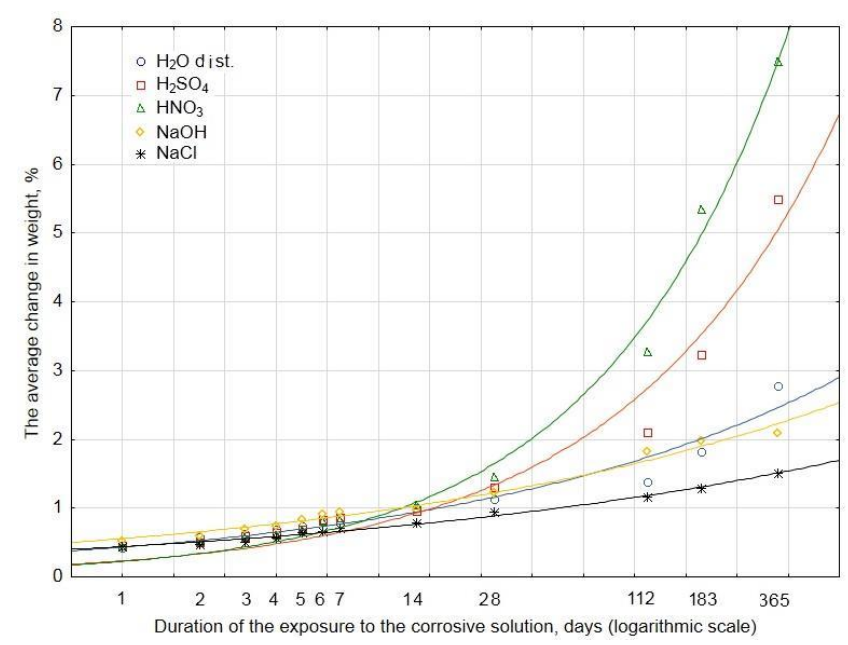

Fig. 1. Trend functions showing weight changes depending on the time of the exposure to each aggressive medium.

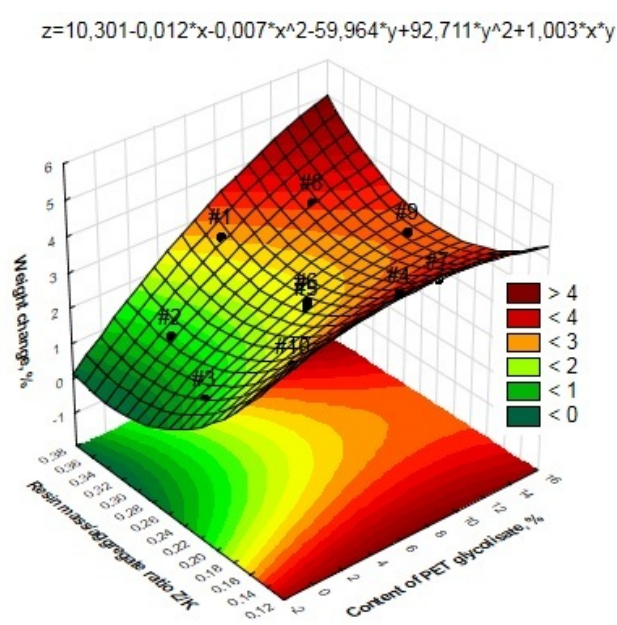

Fig. 2. Spatial diagram of response surface for specimens weight change after 12 months of exposure in distilled water

The trend functions adjusted to the results of the measurements are shown in Fig. 1] The values of the function equation coefficients ( $\mathrm{a}$ and $\mathrm{b}$ ) and determination coefficients $\left(R^{2}\right)$ are given in Table 2

The values of the determination coefficient $\mathrm{R}^{2}$ within the range of $<0.93845-0.99105>$ signify that the function is very well adjusted to the results of the measurements.

The determination coefficient of over $93 \%$ explains the dependence of the average weight change of the mortar samples on the duration of submersion in a specific corrosive medium. Each of the five corrosive solutions used increases the weight of the mortar samples tested during exposure. It can be noticed that during the first 7 submersion days the differences in the average weight changes determined for the individual corrosive solutions differ negligibly. However, they increase as the duration of the exposure gets longer. The trend lines obtained for water and sodium hydroxide solution are similar. 


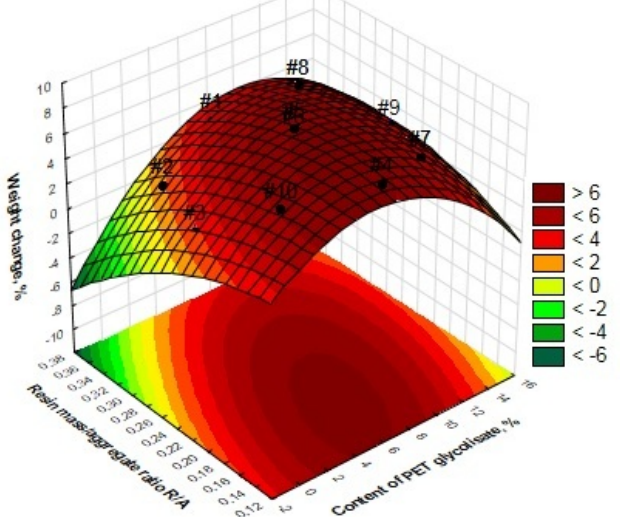

Fig. 3. Spatial diagram of response surface for specimens weight change after 12 months of exposure in $10 \%$ solution of sulphuric acid

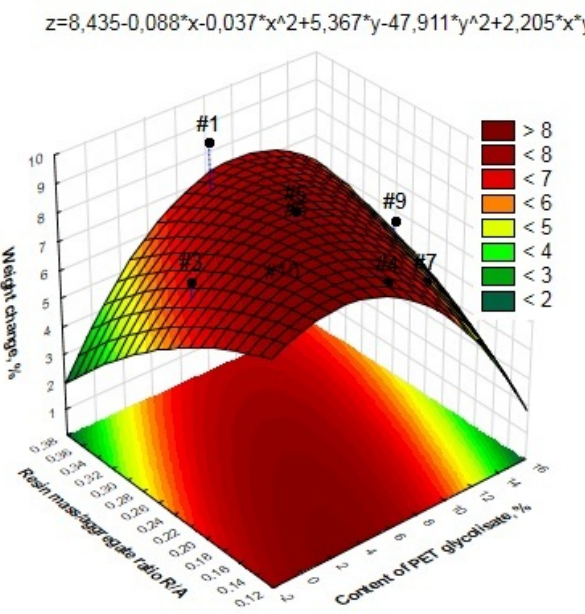

Fig. 4. Spatial diagram of response surface for specimens weight change after 12 months of exposure in $10 \%$ solution of nitric acid

Much larger disproportions occur for sulphuric acid solution, nitric acid solution and sodium chloride solution. At the same time the lowest values of the average weight change were recorded for the samples submerged in $10 \%$ sodium chloride solution whose average weight change did not exceed $2 \%$ after a year-long exposure. The average weight change of mortar submerged in water and in $10 \%$ sodium hydroxide solution fluctuates around $2.5 \%$. Much higher weight changes were recorded for the samples submerged in 10\% sulphuric acid solution and $10 \%$ nitric acid solution.

In this case, the average changes in weight after a year were about $5.5 \%$ and $7.5 \%$, respectively. Considering the small chemical resistance of cement mortars (weight drop by $32 \%$ in 14-day special exposure cycle) [27], the results signify the very good chemical resistance of the mortars examined.

The weight growth observed in the samples can be explained by analysing the phenomena occurring during their exposure to the aggressive media. A hydrolysis of ester bindings of the incorporated fragments of glycolysate and the washing away of the hydrolysis products are possible when resin compositions are left in the solutions. The so formed hollows may be oc-

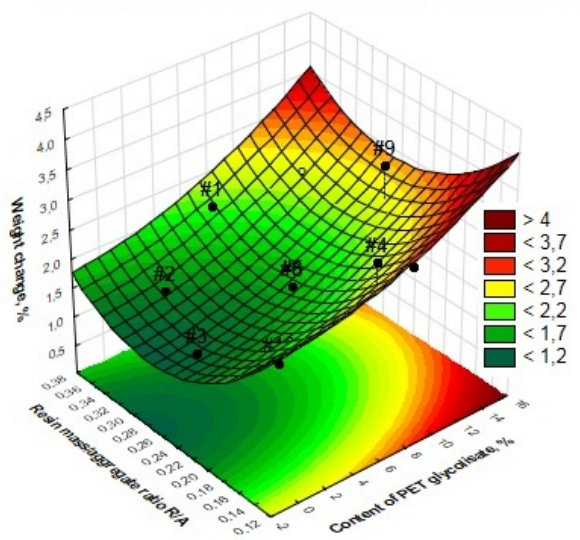

Fig. 5. Spatial diagram of response surface for specimens weight change after 12 months of exposure in $10 \%$ solution of sodium hydroxide

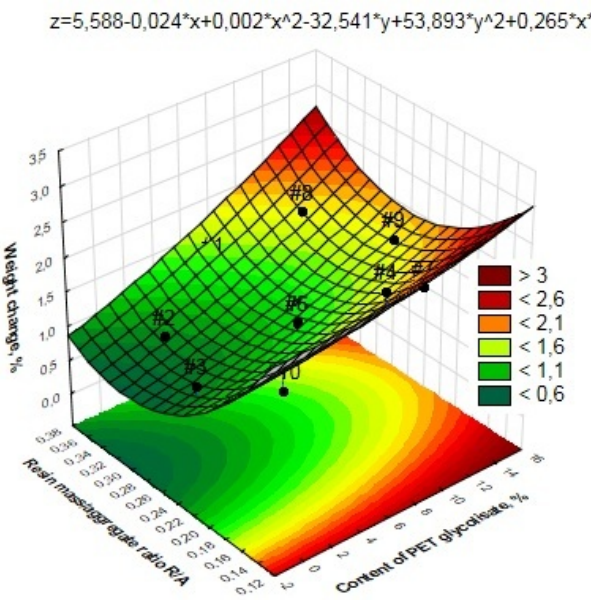

Fig. 6. Spatial diagram of response surface for specimens weight change after 12 months of exposure in $10 \%$ solution of sodium chloride

cupied by particles of water, which increases the weight of the samples. No small cracks were observed on the surface of the test samples, no stratification, bubbles, pitting, etc. However, some of the samples submerged in nitric acid tend to warp. It was noticed that after being submerged for six months the surface of the samples exposed to nitric acid turned yellowish. This effect intensified over the next six months of exposure.

The purpose of the experimental research was also to experimentally define a function describing the effect of the input parameters characterizing the composition of the mortar (percentage content of PET glicolisate, resin/aggregate ratio) on its quality determined by output quantities, i.e. the characteristics subjected to investigation (percentage of weight change). The nature of this effect as well as the variation areas of the input data where output quantities assume the highest values are presented by the diagrams illustrating the response surfaces (Figs. 2. 6) 6 .

The average weight change values obtained at particular points of the experiment plan for modified epoxy mortars exposed to corrosion inducing media are listed in Fig.4

The maximum weight change of the samples of PET glicolisate modified epoxy mortar subjected to the effect of distilled 
Tab. 3. The values of the trend function coefficients and the coefficients of determination for each corrosive solution

\begin{tabular}{cccccc}
\hline $\begin{array}{l}\text { The coefficients of } \\
\text { the equation and } \\
\text { the coefficient of } \\
\text { determination }\end{array}$ & $\mathrm{H}_{2} \mathrm{O}$ dist. & $10 \% \mathrm{H}_{2} \mathrm{SO}_{4}$ & $10 \% \mathrm{HNO}_{3}$ & $10 \% \mathrm{NaOH}$ & $10 \% \mathrm{NaCl}$ \\
\hline $\mathrm{a}$ & 0.679 & 1.120 & 1.368 & 0.541 & 0.481 \\
\hline $\mathrm{b}$ & 0.433 & 0.234 & 0.226 & 0.558 & 0.442 \\
\hline $\mathrm{R}^{2}$ & 0.9384 & 0.9614 & 0.9910 & 0.9805 & 0.9900 \\
\hline
\end{tabular}

Tab. 4. Values of average weight changes after 12 months of exposure to corrosive solutions of particular points of the experiment

\begin{tabular}{cccccc}
\hline No of the plan point & \multicolumn{5}{c}{ Average weight change, \% } \\
\hline 1 & $\mathrm{H}_{2} \mathrm{O}$ dist. & $\begin{array}{c}10 \% \text { solution of } \\
\mathrm{H}_{2} \mathrm{SO}_{4}\end{array}$ & $\begin{array}{c}10 \% \text { solution of } \\
\mathrm{HNO}_{3}\end{array}$ & $\begin{array}{c}10 \% \text { solution of } \\
\mathrm{NaOH}\end{array}$ & $\begin{array}{c}10 \% \text { solution of } \\
\mathrm{NaCl}\end{array}$ \\
\hline 2 & 2.82 & 3.86 & 8.97 & 2.2 & 1.3 \\
\hline 3 & 1.24 & 2.03 & 4.84 & 1.46 & 0.87 \\
\hline 4 & 1.11 & 2.6 & 7.58 & 1.32 & 0.97 \\
\hline 5 & 4.32 & 7.21 & 7.94 & 3.04 & 2.48 \\
\hline 6 & 2.35 & 7.27 & 8.44 & 1.73 & 1.23 \\
\hline 7 & 2.53 & 6.78 & 7.85 & $1 ., 72$ & 1.22 \\
\hline 8 & 3.3 & 5.41 & 6.19 & 2.15 & 1.81 \\
\hline 9 & 3.3 & 5.41 & 6.19 & $2 ., 15$ & 1.81 \\
\hline 10 & 3.25 & 4.28 & 6.62 & 3.08 & 1.8 \\
\hline
\end{tabular}

water and checked after 12 months from the moment of their immersion in the liquid was $3.3 \%$. This weight change was obtained for the mortar composition containing the highest quantity of the modifier added, at the resin/aggregate ratio of 0.33 (point \#8, Table 4). On the other hand, the lowest value of water absorption $(1.11 \%)$ is characteristic of the mortar manufactured without an addition of the modifier (point \#3, Table 4). The amount of the water absorbed by the modified epoxy mortar is many times lower as compared to a normal cement mortar, which is $4 \div 10 \%$. The results listed in Table 4 prove that the highest weight changes took place in the case of the samples subjected to the effect of $10 \%$ solution of nitric acid.

Definitely the greatest weight increases, for almost all the corrosive media, were noticed in the case of the fourth point of the experiment plan. The composition of the mortar at this point shows the highest content of aggregate in the composite (content of PET glicolisate is $7 \%$, resin/aggregate ratio, $\mathrm{Z} / \mathrm{K}=0.14$ ) which may have resulted in aggregate grains being inadequately coated by the resin, and consequently lower corrosion resistance of the composite.

\section{Conclusions}

If construction materials are in contact with corrosive agents, they deteriorate and lose their durability. The appropriate selection of materials, already at the design and manufacture stage should be considered in order to avoid costly repairs in the future.

The experiments carried out from the basis for the following conclusions:
- The dependence of the weight change of the samples on the time of their exposure to different corrosive solutions can successfully be presented as an exponential trend function.

- The nature of the effect and the variation areas of the parameters describing the composition of the compounds investigated, for which weight change percentage takes the highest values, are shown by the diagrams illustrating response surfaces.

- The samples submerged in the particular aggressive solutions increase their weight as the duration of the exposure gets longer. The lowest weight change value, $0.87 \%$, was recorded for the second point of the plan of the experiment for the samples submerged in $10 \%$ sodium chloride, whereas the highest value, $8.97 \%$, for the first point of the plan for the samples exposed to $10 \%$ nitric acid solution.

- The weight changes of the mortar samples exposed to corrosive agents are much smaller than those of standard mortars described in the literature, which proves very good chemical resistance of modified epoxy mortars.

- Polymer mortars are excellent for use in the chemically aggressive environment. Higher costs due to the presence of polymers in such composites can be effectively lowered by employing modifiers produced from waste materials.

\section{Acknowledgement}

The research work was conducted using the means granted by the Ministry of Education and Schools of Academic Rank as part of the 1943/B/TO2/2010/38 doctorate research project. 
The work was also financially supported by the European social fund as well as by the state budget and the local budget of Subcarpathia, Poland.

\section{References}

1 Xiong G, Chen X, Li G, Chen L, Sulphuric acid resistance of soluble soda glass-polyvinyl acetate latex-modified cement mortar, Cement and Concrete Research, 31, (2001), 83-86, DOI 10.1016/S0008-8846(00)00426-9

2 Książek M, Badania odporności chemicznej polimerowego kompozytu siarkowego do betonu, Ochrona przed korozją, 6, (2010), 322-324.

3 Garbacz A, Sokołowska JJ, Concrete-like polymer composites with fly ashes - Comparative study, Construction and Building Materials, 38, (2013), 689-699, DOI 10.1016/j.conbuildmat.2012.08.052

4 Jo YK, Basic properties of epoxy cement mortars without hardener after outdoor exposure, Construction and Building Materials, 22, (2008), 911-920, DOI 10.1016/j.conbuildmat.2006.12.006

5 Xiao L, Jin Y, Gu L, Preparation and Properties of a New Composite of Epoxy Emulsion (EEM) Modified Cement, Journal of Wuhan University of Technology-Mater, (2009), 843-845, DOI 10.1007/s11595-009-5843-5

6 Aggarwal LK, Thapliyal PC, Karade SR, Properties of polymer-modified mortars using epoxy and acrylic emulsions, Construction and Building Materials, 21, (2007), 379-383, DOI 10.1016/j.conbuildmat.2005.08.007

7 Zhong S, Chen Z, Properties of latex blends and its modified cement mortars, Cement and Concrete Research, 32, (2002), 1515-1524, DOI 10.1016/S0008-8846(02)00813-X

8 Januszewski M, Zaprawy odporne na środowiska agresywne, Środkowo Pomorskie Towarzystwo Naukowe Ochrony Środowiska, 11, (2009), 497506.

9 Benosman AS, Taibi H, Mouli M, Belbachir M, Senhadji Y, Diffusion of chloride ions in polymer-mortar composites, Journal of Applied Polymer Science, 110, (2008), 1600-1605, DOI 10.1002/app.28587

10 Tawfik ME, Eskander SB, Polymer concrete from Marble Wastes and Recycled Poly(ethylene terephthalate), Journal of Elastomers and Plastics, 38, (2006), 65-79, DOI 10.1177/0095244306055569

11 Jo BW, Park SK, Park JC, Mechanical properties of polymer concrete made with recycled PET and recycled concrete aggregate, Construction and Building Materials, 22, (2008), 2281-2291, DOI 10.1016/j.conbuildmat.2007.10.009

12 Dębska B, Lichołai L, Badanie możliwości wykorzystania modyfikowanych zapraw epoksydowych $w$ procesach naprawczych betonów. Cz. 1. Oznaczenie wtaściwości wytrzymatościowych, absorpcji wody oraz odporności chemicznej, Zeszyty Naukowe Politechniki Rzeszowskiej. Budownictwo i Inżynieria Środowiska, 59, (2012), 149-159.

13 Gorninski JP, Dal Molin DC, Kazmierczak CS, Strength degradation of polymer concrete in acidic environments, Cement and Concrete Composites, 29, (2007), 637-645, DOI 10.1016/j.cemconcomp.2007.04.001

14 Reis JML, Mechanical characterization of polymer mortars exposed to degradation solutions, Construction and Building Materials, 23, (2009), 3328-3331, DOI 10.1016/j.conbuildmat.2009.06.047

15 Ribeiro MCS, Novoa PR, Ferreira AJM, Marques AT, Flexural performance of polyester and epoxy polymer mortars under severe thermal conditions, Cement and Concrete Composites, 26, (2004), 803-809, DOI 10.1016/S0958-9465(03)00162-8

16 Reis JML, Ferreira AJM, The effects of atmospheric exposure on the fracture properties of polymer concrete, Building and Environment, 41, (2006), 262-267, DOI 10.1016/j.buildenv.2004.12.017

17 Silva MAG, Silva ZCG, Simão J, Petrographic and mechanical aspects of accelerated ageing of polymeric mortars, Cement and Concrete Composites, 29, (2007), 146-156, DOI 10.1016/j.cemconcomp.2006.08.003

18 Reis JML, Ferreira AJM, Effect of marine exposure on fracture prop- erties of epoxy concretes, Polymer Testing, 24, (2005), 121-125, DOI 10.1016/j.polymertesting.2004.06.002

19 Lichołai L, Dębska B, A study of the effect of corrosive solutions on selected physical properties of modified epoxy mortars, Construction and Building Materials, 65, (2014), 604-611, DOI 10.1016/j.conbuildmat.2014.05.038

20 Dębska B, Modification of Polymer Composites by Polyethylene Terephthalate Waste, In:, pp. 195-212, DOI 10.1016/B978-0-323-31306-3.00010-5

21 Czarnecki L, Polymer concretes, Cement-Lime-Concrete, 2, (2010), 63-85.

22 Czarnecki L, Łukowski P, Influence of polymer admixtures and additives on durability of concrete, Cement-Lime-Concrete, 1, (2004), 38-47.

23 Czarnecki L, Betony żywiczne, Arkady; Warszawa, 1982.

24 Czarnecki L, Betony polimerowe, XVII Ogólnopolska Konferencja Warsztat Pracy Projektanta Konstrukcji (Ustroń, Poland, 2002-02-20), In:.

25 Lichołai L, Dębska B, The multidimensional response function exemplified by epoxy mortars: Looking for the global extreme, Archives of Civil and Mechanical Engineering, 14, (2014), 644-645, DOI 10.1016/j.acme.2013.11.005

26 Dębska B, Lichołai L, The selected mechanical properties of epoxy mortar containing PET waste, Construction and Building Materials, 94, (2015), 579-588, DOI 10.1016/j.conbuildmat.2015.07.031

27 Reis JML, Fracture assessment of polymer concrete in chemical degradation solutions, Construction and Building Materials, 24, (2010), 1708-1712, DOI 10.1016/j.conbuildmat.2010.02.020 